\title{
PiroPinus: a spreadsheet application to guide prescribed burning operations in maritime pine forest
}

\author{
Paulo M. Fernandes ${ }^{1}$, Carlos Loureiro, Hermínio Botelho \\ Centro de Investigação e de Tecnologias Agro-Ambientais e Biológicas (CITAB), \\ Universidade de Trás-os-Montes e Alto Douro, Portugal
}

\author{
ARTICLE INFO \\ Article history: \\ Received 18 September 2011 \\ Received in revised form 1 November \\ 2011 \\ Accepted 20 November 2011 \\ Keywords: \\ Decision support \\ Fire management \\ Prescribed burning \\ Microsoft Excel
}

\begin{abstract}
The efficient, sustainable and safe use of prescribed burning is based on quantitative application guidelines. PiroPinus was conceived for operational support to lineignited, hazard-reduction burning in maritime pine (Pinus pinaster) forest, but can be used as a modelling tool for surface fire behaviour in general. PiroPinus rests on a sound empirical foundation and links the fire environment (fuel, weather, terrain), fire behaviour characteristics, and fire effects on fuels and trees. PiroPinus produces burn prescriptions and predictions that match site-specific treatment objectives and environmental conditions, and enables post burn assessments of treatment effectiveness and impact. Implementation in Microsoft Excel facilitates improvement, expansion and custom modification.
\end{abstract}

(C) 2012 Elsevier B.V. All rights reserved

\section{Introduction}

Prescribed burning (PB) is a regular component of forest management and silviculture in temperate and mediterranean regions, namely in North America and Australia (Pyne et al., 1996). PB is the deliberate use of fire under defined environmental conditions, the prescription, to achieve a given management objective (Wade and Lundsford, 1988; Tolhurst and Cheney, 1999). One major goal of PB is to mitigate fire hazard by reducing flammable fuels accumulated in the understory, while limiting fire severity, i.e. the impacts on trees and the soil. PB treatments should seek specific and well-formulated quantitative objectives (Wade and Lundsford, 1988), e.g. to decrease fine fuel loading by $75 \%$. Consequently, PB is framed by land management goals and site-specific conditions, and because of the risk implied is both conditioned by environmental and social restrictions and is under continuous public scrutiny. Inherent to PB is the adoption of formal, standardized procedures to plan and evaluate burn operations (Pyne et al., 1996). The prescription is critically important because it translates the fire environment - i.e. vegetation (fuel), weather, and topography - into the physical properties of fire (fire behaviour) and these into fire effects (e.g. fuel consumption, tree mortality). The planning and decision-making process of PB benefits from decision support tools that will assist in maximizing the benefits while avoiding or minimizing negative impacts.

\footnotetext{
1 Corresponding author. Address: Apartado 1013, 5001-801 Vila Real, Portugal. Tel.: +351 259 350885; fax: +351 259 350480 .

E-mail address: pfern@utad.pt (P.M. Fernandes).
} 
Decision-support tools for PB address distinct objectives and scales, and therefore vary widely, from general prescriptions and guidelines (e.g. Kilgore and Curtis, 1987; Wade and Lunsford, 1988) to complex software and programming addressing the spatial or seasonal dimensions of PB planning (e.g. Higgins et al., 2011). Australian PB guides are rooted in field experimentation and consist of tables and graphs that are used to estimate fire characteristics and effects in specific vegetation types (e.g. Sneeuwjagt and Peet, 1985). PB operations in North America rely on fire behaviour and effects models and software (Forestry Canada Fire Danger Group, 1992; Andrews 2007). Expert systems have also been proposed to assist with PB planning (Reinhardt et al., 1989; Pivello and Norton, 1996).

Maritime pine (Pinus pinaster Ait.) is an important and fire-prone west Mediterranean conifer (Fernandes and Rigolot 2007). Portuguese maritime pine forests in public land are the subject of hazard-reduction PB programs since the 1980s. However, a need to improve PB planning and evaluation to better attain hazard reduction without significant environmental impact has been recognized (Fernandes and Botelho 2004). Field experimentation (Fernandes et al., 2008, 2009) was carried out to improve the understanding of surface fire behaviour and effects (canopy scorch, tree mortality, fuel consumption) that would lead to quantitative linkages between the fire environment and the objectives and outcomes of a PB operation. Here we present PiroPinus, corollary of the experimental and modelling efforts.

Table 1. Sources for the equations and tables used in PiroPinus.

\begin{tabular}{|c|c|c|}
\hline Module & aOutput type & Source \\
\hline FUEL & Env & Fernandes et al. (2002) \\
\hline RX DEV & Env, Beh & Fernandes (2002) \\
\hline MOIST & Env & Rothermel (1983); Fernandes et al. (2000) \\
\hline FIRE & Beh & Hirsch and Martell (1996); Fernandes et al. $(2008,2009)$ \\
\hline TREES & Ef & Fernandes (2002); Vega et al. (2010) \\
\hline FUEL DYN & Ef & $\begin{array}{l}\text { Vega et al. (2000); Fernandes (2002); Fernandes et al. } \\
(2002)\end{array}$ \\
\hline POST-FIRE & Beh, Ef & $\begin{array}{l}\text { Fernandes (2002); Fernandes et al. (2002); Vega et al. } \\
(2010)\end{array}$ \\
\hline WEATH & Env & $\begin{array}{l}\text { Albini and Baughman (1979); Rothermel (1983); Finney } \\
\text { (1998); Fernandes (2002); Fernandes et al. (2008) }\end{array}$ \\
\hline
\end{tabular}

\section{Approach and description}

Empirically based models guide fire management operations, now and in the foreseeable future (Sullivan, 2009). PiroPinus is based on a self-contained chain of empirical predictive relationships between descriptors of the fire environment, fire behaviour, and fire effects (Fig. 1). Overall structure was determined by the need to achieve efficient fuel consumption while constraining fire severity, as expressed by impact on trees and the forest floor (Fernandes and Botelho, 2004). PiroPinus was conceived from natural fuels data, i.e. slash from pruning or thinning was not present, and accounts for first-order fire effects only, those that immediately follow fire as a direct result of it (Reinhardt et al., 1997). Secondary fire effects (on soil properties, plant regeneration, vegetation succession) are not accounted for PiroPinus, as they depend partially on first-order effects but occur 
on the medium- to long-term and result from complex interactions between variables. PiroPinus runs as a Microsoft Excel workbook and comprises 10 interrelated or stand-alone sheets that implement the selected equations and other sources of information (Table 1). Input and output variables are listed and described in the Appendix. The component sheets, their outputs and the input-output flow of PiroPinus are indicated in Fig. 2.

Fuel loading determines heat release, i.e. fire intensity, and is important to select priority areas for treatment and to prescribe fuel consumption. Hence, fuel-loading appraisal is crucial when hazard reduction is the main target of PB. Basic fuel data from a field survey are entered on FUEL (Fuel and Stand Description worksheet) to quantify fuel loading by fuel layer and other fuel descriptors that influence fire behaviour and effects. Additionally, data on stand characteristics is entered on FUEL for further calculation of fire-induced tree damage.

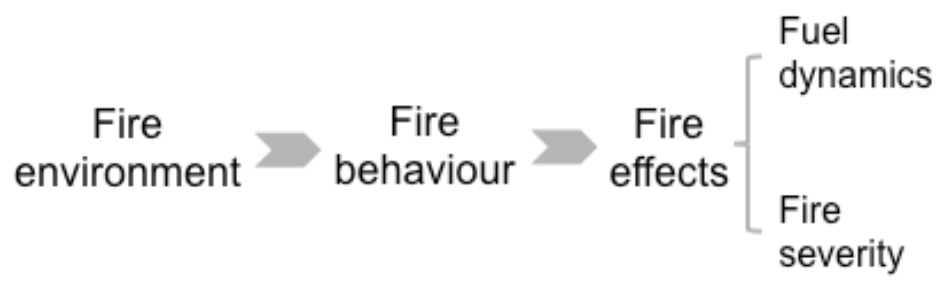

Fig. 1. PiroPinus general structure.

Worksheet RX WIN (Burning Window) does not interact with other PiroPinus components and consists of a general burn prescription for maritime pine, defined by ranges in weather conditions and fuel moisture contents (Fernandes and Botelho, 2004). Burn prescriptions are actually developed in RX DEV (Prescription Development worksheet). The user indicates the maximum acceptable fire severity in terms of forest floor consumption and crown scorch, i.e. the extent of heat-killed foliage. PiroPinus estimates the intervals for lower litter moisture content and flame length that satisfy the restrictions.

Fuel moisture content is arguably the single most important variable to consider when planning PB. Fuel moisture is decisive in determining whether or not a fire will spread and its physical characteristics, the type and amount of fuels consumed and, indirectly, impact on the overstorey. MOIST (Fuel Moisture worksheet) estimates the moisture content of fine dead fuels from ambient weather and time since rain, with a correction for the factors affecting fuel exposure to solar radiation. The Duff Moisture Code of the Canadian Forest Fire Weather Index System (Forestry Canada Fire Danger Group, 1992) is an acceptable surrogate for the moisture content of lower litter (Fernandes, 2002) and is used in its estimation.

Worksheet FIRE (Fire Behaviour) is the core of PiroPinus and computes the sustainability and fire behaviour characteristics of a line-ignited surface fire. The output individualizes head- and backfire spread, i.e. burning with or against the wind. Poor assessment of the potential for selfsustained flaming had been identified as a PB operational bottleneck (Fernandes and Botelho, 2004). Estimates of fire-spread rate are essential to quantify flame size and fire intensity, and are useful to optimize the schedule and layout of ignition in IGN PLAN (Ignition Planning worksheet). Flame length and fire intensity are related with fire suppression difficulty and the upward component of fire severity, which makes their prediction important to prevent fire escapes and to constrain tree damage to a desired level. FIRE includes a table to interpret fire intensity classes in terms of burn effectiveness, tree damage and fire control requirements.

Control of tree injury is a primary concern of a PB manager, either to avoid or to enhance tree mortality (when a thinning effect is desired), avert loss of tree growth, and minimize the possibility 
of insect attacks. Crown scorch is the main driver of tree mortality and is predicted in absolute and relative terms by TREES (Fire Impacts on Trees worksheet). Backfire and headfire probabilities of mortality are computed for the average-sized tree, as well as for specific tree sizes specified by the user.

\begin{tabular}{|c|c|c|}
\hline 2. RX WIN & 9. POST-FIRE & 10. WEATH \\
\hline Generic prescription & Fire behaviour characteristics & Surface wind speed \\
\hline 3. RX DEV & $\begin{array}{l}\text { Fuel consumption } \\
\text { Needle fall }\end{array}$ & $\begin{array}{l}\text { Fire spread sustainability } \\
\text { (FWI) }\end{array}$ \\
\hline Prescription & Crown scorch & Fuel consumption (FWI) \\
\hline 4 & Probability of mortality & \\
\hline 1. FUEL & & \\
\hline Loading by fuel layer & 5. FIRE & \\
\hline & Fire spread sustainability & \\
\hline$\downarrow$ & $\begin{array}{l}\text { Fire behaviour characteristics } \\
\text { Fire behaviour interpretation }\end{array}$ & \\
\hline 7. TREES & 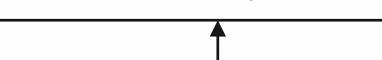 & $\downarrow$ \\
\hline Crown scorch & & 6. IGN PLAN \\
\hline Probabinty of mortainty & & Treatment rate \\
\hline$\downarrow$ & & Unit sub-division \\
\hline 8. FUEL DYN & 4. MOIST & \\
\hline Fuel consumption & Dead fuel moisture contents & \\
\hline Post-burn fuel accumulation & & \\
\hline
\end{tabular}

Fig. 2. Components and input-output flow diagram of PiroPinus. The arrows show the logical flow direction. Text within boxes indicates the outputs of each component. Components and outputs in grey are static. RX WIN and WEATH are independent components, and RX DEV, IGN PLAN and POST-FIRE can also be run autonomously.

FUEL DYN (Fuel Dynamics worksheet) estimates absolute and relative fuel consumption by fuel layer and the ensuing fuel build-up over time. Post-burn needle fall is included in the calculations. Hence, FUEL DYN assesses both the immediate effectiveness of PB and the hazard-reduction longevity of the treatment, which helps in scheduling the next treatment.

Data collection is a trivial procedure in $\mathrm{PB}$, and is part of the planning and monitoring process that seeks improvement of performance over time. POST-FIRE (Post-Fire Assessment worksheet) uses post-burn measurements to estimate fire behaviour and effects on fuels and trees. This enables an independent assessment of PB compliance with the prescription and its success in attaining the stated objectives.

WEATH (Weather for Prescribed Fire Planning) is the final worksheet in PiroPinus. WEATH converts forecasted wind speeds or Beaufort-scale wind assessments into surface in-stand wind speeds by taking stand structure into account. For sub-regional to regional PB planning, fire-spread sustainability and fuel consumption are related to codes of the Canadian Forest Fire Weather Index System (Forestry Canada Fire Danger Group, 1992), responding to the operational need of identifying suitable days for $\mathrm{PB}$. 


\section{Discussion and conclusion}

PiroPinus is an all-in-one model, whose outputs reflect real-world fire behaviour and effects, as it is mostly based on extensive experimentation. Fire modelling systems based on the model of Rothermel (1972), such as BehavePlus (Andrews, 2007), offer reasonably accurate estimates of fire behaviour characteristics in maritime pine stands, provided that fine-tuned custom fuel models are used (Cruz and Fernandes, 2008). However, their performance is poor when fuel moisture content is high (Cruz et al., 2008); an added value of PiroPinus is that it quantifies fire-spread uncertainty under marginal burning conditions, corresponding to dead fuel moisture contents $>20 \%$ (Fernandes et al., 2008). An even more significant feature is the ability to account for local fuel and stand conditions in the output, whereby site-specific prescriptions and predictions are made for specific site conditions. This is beyond the current capacity of fuel modelling, as a proposed reformulation of Rothermel's model to directly estimate fire behaviour in specific fuel complexes (Sandberg et al., 2007) remains to be validated.

The empirical nature of PiroPinus advises against extrapolation to conditions beyond the experimental range of development. Nonetheless, Ascoli et al. (2010) used PiroPinus in a Pinus halepensis stand in Italy with remarkable success. This suggests that PiroPinus could be adapted for use in other medium to long-needled mediterranean pines (Pinus pinea, P. canariensis, P. brutia, $P$. halepensis, $P$. nigra, $P$. radiata), namely through adjustment factors based on the literature or on limited experimental data.

The modular and spreadsheet approach of PiroPinus confers high flexibility, for both basic and advanced users. End-users are usually familiar with Excel and individual versions, prescriptions and model runs can be readily saved, stored and shared. Access to the equations facilitates understanding of model functioning and the role of each input variable. Potential users are encouraged to edit cell formulae and worksheets to suit their needs or introduce modifications as new knowledge becomes available. Room for improvement is particularly apparent in regards to fuel moisture content estimation and the diurnal variation of weather variables and fire behaviour (Beck and Trevitt, 1989). PiroPinus was primarily developed to assist with PB operations, but the equations' application bounds support the prediction of surface fire characteristics in general (Fernandes et al., 2009), i.e. up to a fire intensity of 1500 to $4000 \mathrm{~kW} \mathrm{~m}^{-1}$, depending on canopy base height (Cruz et al., 2005). Hence, a broader scope of application is warranted and PiroPinus can be used as a fire-modelling research tool, as in Ascoli et al. (2010).

PiroPinus (available at http://fireintuition.efi.int/products/piropinus.fire) is user-friendly, portable, cost-effective and adaptable, and is being used for PB training and planning in Portugal. PiroPinus complements the skills and experience of fire managers, and increases their competence by reconciling efficient fuel reduction with low-impact burn operations.

\section{Acknowledgments}

PiroPinus was developed in the frame of projects PEAM/IF/0009/97 and FIRE TORCH (ENV4CT98-0715/DGXII/CE). The update, expansion and English version were made in the frame of the FIRE PARADOX project (FP6-018505). We thank Davide Ascoli and the anonymous reviewers for useful comments.

\section{References}

Albini, F.A., Baughman, R.G., 1979. Estimating Windspeeds for Predicting Wildland Fire Behavior. Res. Pap. INT-221, USDA Forest Service, Intermountain Forest and Range Experiment Station, Ogden, Utah. 
Andrews, P.L., 2007. BehavePlus Fire Modeling System: Past, Present, and Future. In: Proc. 7th Symposium on Fire and Forest Meteorological Society, American Meteorological Society, Boston, 13 p.

Ascoli, D., Esposito, A., Seneca, U., Strumia, S., Rutigliano, F.A., Catalanotti, A.E., Salgueiro, A., Palheiro, P., Rebelo, A., Mazzoleni, S., Bovio, G., Fernandes, P., 2010. Using Piropinus to assess fuel reduction effectiveness of prescribed burning in a Pinus halepensis plantation in southern Italy. In: Viegas, D.X. (Ed.), Proc. VI International Conference on Forest Fire Research, ADAI, Coimbra. CD-ROM.

Beck, J.A., Trevitt, A.C., 1989. Forecasting diurnal variations in meteorological parameters for predicting fire behaviour. Can. J. For. Res. 19, 791-797.

Cruz, M.G., Alexander, M.E., Fernandes, P.M., 2008. Development of a model system to predict wildfire behaviour in pine plantations. Aust. For. 71, 113-121.

Cruz, M.G., Alexander, M.E., Wakimoto, R.W. 2005. Development and testing of models for predicting crown fire rate of spread in conifer forest stands. Can. J. For. Res. 35, 1626-1639.

Cruz, M.G., Fernandes, P.M., 2008. Development of fuel models for fire behavior prediction in maritime pine (Pinus pinaster Ait.) stands. Int. J. Wildland Fire 17, 194-204.

Fernandes, P., Botelho, H., Loureiro, C., 2000. Modelling the Links Between Environmental Conditions, Fire Behavior and Fire Effects Important for Prescribed Burning Operational Purposes. Task 6 - Deliverable F1 of the Fire Torch project: Prescribed Burning as a Tool for the Mediterranean Region. ENV4-CT98-0715, European Commission, DG XII, Science, Research and Development, Programme: Environment and Climate.

Fernandes, P.M., 2002. Desenvolvimento de Relações Preditivas para Uso no Planeamento de Fogo Controlado em Povoamentos de Pinus pinaster Ait. Ph.D. thesis, UTAD, Vila Real.

Fernandes, P.M., Botelho, H.S., 2004. Analysis of the prescribed burning practice in the pine forest of northwestern Portugal. J. Environ. Manage. 70, 15-26.

Fernandes, P.M., Botelho, H.S., Rego, F.C., Loureiro, C., 2008. Using fuel and weather variables to predict the sustainability of surface fire spread in maritime pine stands. Can. J. For. Res. 38, 190-201.

Fernandes, P.M., Botelho, H.S., Rego, F.C., Loureiro, C., 2009. Empirical modelling of surface fire behaviour in maritime pine stands. Int. J. Wildland Fire 18, 698-710.

Fernandes, P.M., Botelho, H.S., Rego, F.C., Loureiro, C., 2009. Empirical modelling of surface fire behaviour in maritime pine stands. Int. J. Wildland Fire 18, 698-710.

Fernandes, P.M., Loureiro, C., Botelho, H., Ferreira, A., Fernandes, M., 2002. Avaliação indirecta da carga de combustível em pinhal bravo. Silva Lusitana 10, 73-90.

Fernandes, P.M., Rigolot, E., 2007. The fire ecology and management of maritime pine (Pinus pinaster Ait.). For. Ecol. Manage. 241, 1-13.

Finney, M.A., 1998. FARSITE: Fire Area Simulator - Model Development and Evaluation. USDA For. Serv. Res. Pap. RMRS-RP-4, Rocky Mte. Res. Stn., Ogden.

Forestry Canada Fire Danger Group, 1992. Development and Structure of the Canadian Forest Fire Behavior Prediction System. For. Can. Inf. Rep. ST-X-3, Ottawa.

Higgins, A., Whitten, S., Slijepcevic, A., Fogarty, F., Laredo, L., 2011. An optimisation modelling approach to seasonal resource allocation for planned burning. Int. J. Wildland Fire 20, 175-183.

Hirsch, K.G., Martell, D.L., 1996. A review of initial attack fire crew productivity and effectiveness. Int. J. Wildland Fire 6, 199-215.

Kilgore, B.M., Curtis, G.A., 1987. Guide to Understory Burning in Ponderosa Pine-larch-fir Forests in the Intermountain West. USDA For. Serv. Gen. Int. Rep. INT-233, Intermt. Range and Exp. Stn., Ogden.

Pivello, V.R., Norton, G.A., 1996. FIRETOOL: an expert system for the use of prescribed fires in Brazilian savannas. J. Appl. Ecol. 33, 348-356.

Pyne, S.J., Andrews, P.L., Laven, R.D., 1996. Introduction to Wildland Fire. 2nd ed. John Wiley \& Sons, New York. 
Reinhardt, E., Wright, A.H., Jackson, D.H., 1989. An advisory expert system for designing fire prescriptions. Ecol. Modell. 46, 121-133.

Reinhardt, E.D., Keane, R.E., Brown, J.K., 1997. First Order Fire Effects Model: FOFEM 4.0, User's Guide. USDA For. Serv. Intermt. Res. Stn. Gen. Tech. Rep. INT-GTR-344, Ogden.

Rothermel, R.C., 1972. A Mathematical Model for Predicting Fire Spread in Wildland Fuels. USDA For. Serv. Res. Pap. INT-115, Intermt. For. and Range Exp. Stn., Ogden.

Rothermel, R.C., 1983. How to Predict the Spread and Intensity of Forest and Range Fires. USDA For. Serv. Gen. Tech. Rep. INT-143, Intermt. For. and Range Exp. Stn., Ogden.

Sandberg, D.V., Riccardi, C.L., Schaaf, M.D., 2007. Reformulation of Rothermel's wildland fire behaviour model for heterogeneous fuelbeds. Can. J. For. Res. 37, 2438-2455.

Sneeuwjagt, R.J., Peet, G.B., 1985. Forest Fire Behaviour Tables for Western Australia. 3rd ed. West. Austr. Dept. Conserv. and Land Manage., Perth.

Sullivan, A.L., 2009. Wildland surface fire spread modelling, 1990-2007. 2: Empirical and quasi-empirical models. Int. J. Wildland Fire 18, 369-386.

Tolhurst, K.G., Cheney, N.P., 1999. Synopsis of the Knowledge Used in Prescribed Burning in Victoria. Dept. Natural Resources and Environment, Victoria.

Vega, J.A., Cuiñas, P., Fonturbel, M.T., Fernández, C., 2000. Planificar la prescripción para reducir combustibles y disminuir el impacto sobre el suelo en las quemas prescritas. Cuadernos de la Sociedad Española de Ciencias Forestales 9, 189-198.

Vega, J.A., Fernandes, P.M., Defossé, G., Conedera, M., Bravo, S., Cassagne, N., Dupuy, J.L., Fernandes, M.M., Jiménez, E., Lucini, L., Leiva, M., Rigolot, E., Loureiro

C., Kunst, C., Valette, J.C., Pezzatti, G.B., Botelho, H.S., Portier, D., Pérez, J.R., Petit, P., Ledesma, R., Maréchal, J., Godoy, J., Pimont, F., Navarrete, V., 2010. Tree resistance to fire: final results. Deliverable D3.2-6, Fire Paradox, Project no. FP6-018505, European Commission.

Wade, D.D., Lunsford, J.D., 1989. A Guide for Prescribed Fire in Southern Forests. USDA For. Serv. Tech. Pub. R8-TP 11, Southern Region, Atlanta. 


\section{Appendix}

Table A.1. PiroPinus model input and output variables and description, with units where applicable

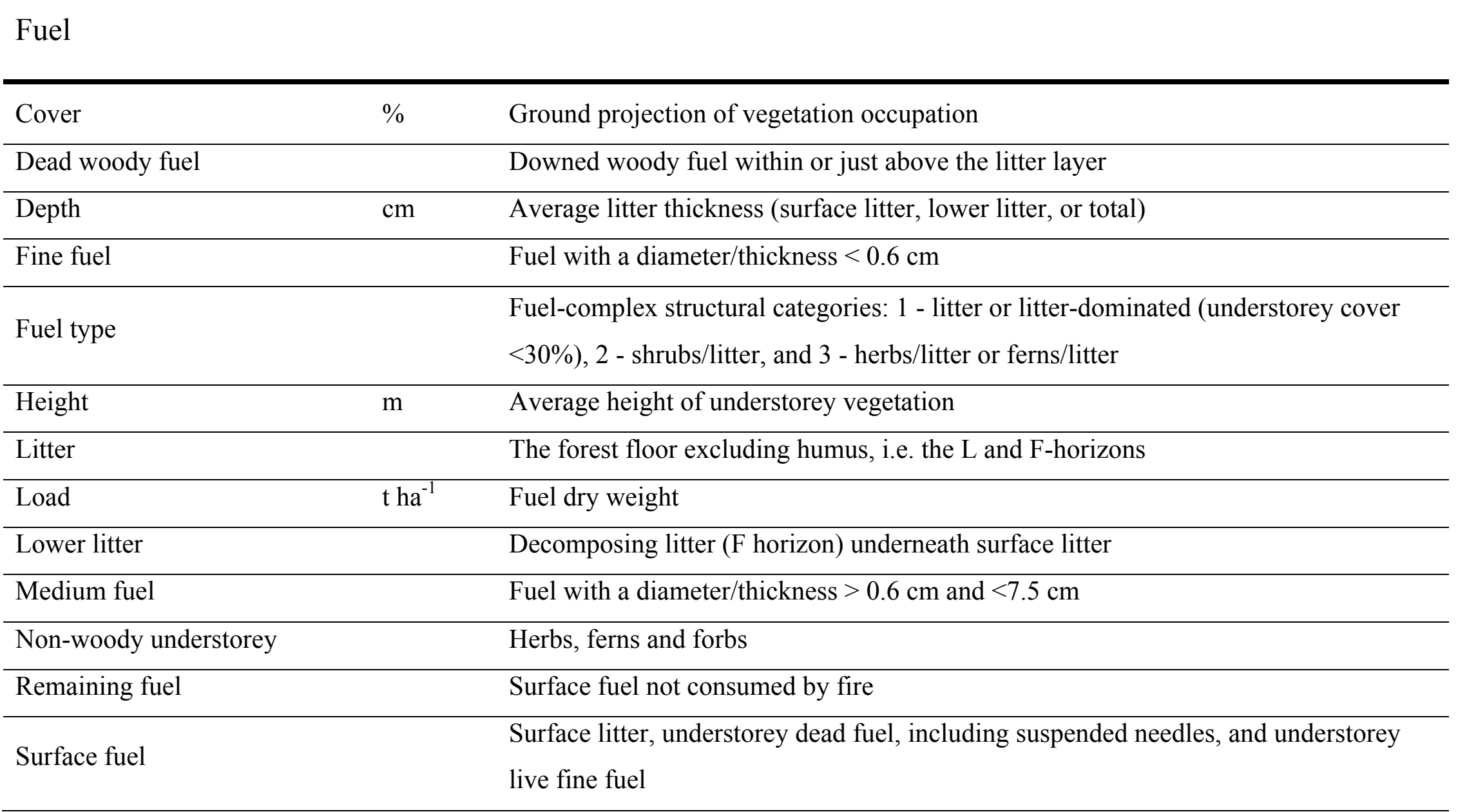




\begin{tabular}{|c|c|c|}
\hline Surface litter & & Fresh, undecomposed, litter (L horizon) \\
\hline \multicolumn{3}{|l|}{ Stand } \\
\hline Canopy cover & $\%$ & Ground projection of the canopy \\
\hline Crown base height & $\mathrm{m}$ & Mean distance from the ground to the live crown base \\
\hline Diameter at breast height & $\mathrm{cm}$ & Mean tree diameter at $1.3-\mathrm{m}$ height \\
\hline Height & $\mathrm{m}$ & Average tree or stand height \\
\hline Tree density & $\mathrm{ha}^{-1}$ & No. trees per unit area \\
\hline \multicolumn{3}{|c|}{ Weather and fuel moisture } \\
\hline Days since last rainfall & & No. of days since the last significant $(>1.5 \mathrm{~mm})$ rainfall event \\
\hline $\mathrm{DMC}$ & & $\begin{array}{l}\text { Duff Moisture Code of the Canadian Forest Fire Weather Index System which } \\
\text { describes the moisture content of the duff }(\mathrm{F} \text { and } \mathrm{H}) \text { horizons of the forest floor }\end{array}$ \\
\hline Fuel moisture content & $\%$ & Water content in relation to fuel dry weight \\
\hline FWI & & $\begin{array}{l}\text { Fire Weather Index of the Canadian Forest Fire Weather Index System that indicates } \\
\text { potential fire intensity }\end{array}$ \\
\hline ISI & & $\begin{array}{l}\text { Initial Spread Index of the Canadian Forest Fire Weather Index System that } \\
\text { represents the combined effects of fuel moisture content and windspeed on rate of } \\
\text { fire spread }\end{array}$ \\
\hline Relative humidity & $\%$ & Ratio between the atmosphere vapour pressure and its saturation atmosphere \\
\hline Season & & May-July $=1 ;$ February-April and August-October $=2 ;$ November-January $=3$ \\
\hline
\end{tabular}




\begin{tabular}{|c|c|c|}
\hline Surface windspeed & $\mathrm{km} \mathrm{hr}^{-1}$ & In-stand windspeed at 1.5-2 $\mathrm{m}$ height (5-minutes average) \\
\hline Temperature & ${ }^{\circ} \mathrm{C}$ & Ambient air temperature \\
\hline \multicolumn{3}{|l|}{ Terrain } \\
\hline Slope & o & Terrain steepness \\
\hline \multicolumn{3}{|l|}{ Fire behaviour and effects } \\
\hline Burn season & & October-March = 1, April-June $=-1$ \\
\hline Byram's fire intensity & $\mathrm{kW} \mathrm{m} \mathrm{m}^{-1}$ & Rate of heat release in the flaming zone \\
\hline Crown scorch height & $\mathrm{m}$ & $\begin{array}{l}\text { Mean distance from the ground to the line separating foliar necrosis (brown needles) } \\
\text { from undamaged canopy }\end{array}$ \\
\hline Relative crown scorch height & & Ratio between crown scorch height and tree height \\
\hline Crown scorch ratio & & Ratio between crown scorch length and total crown length \\
\hline Flame height & $\mathrm{m}$ & Vertical distance between flame tip and the ground surface \\
\hline Flame length & $\mathrm{m}$ & Flame tip to ground distance, measured along the flame axis \\
\hline Fuel consumption & $\mathrm{t} \mathrm{ha}^{-1}, \%$ & Absolute or relative quantity of burnt fuel \\
\hline Marginal fire spread & & Quality of a fire with interruptions in the flame front \\
\hline Needle fall & $\mathrm{t} \mathrm{ha}^{-1}$ & Quantity of scorched needles falling after the fire \\
\hline Productivity & ha $h^{-1}$ & Area treated per unit of time and ignition line \\
\hline Rate of spread & $\mathrm{m} \mathrm{hr}^{-1}$ & Distance of fire spread per unit of time \\
\hline
\end{tabular}


Shrub's stem diameter

Stem char height

Sustained fire spread $\mathrm{mm}$

$\mathrm{m}$

Mean post-burn terminal diameter of the remaining shrub twigs and branches

Vertical distance from ground level to the upper limit of blackened tree trunks

Quality of a self-sustained fire 